\title{
Influence of Bath Temperature, Deposition Time and [S]/[Cd] Ratio on the Structure, Surface Morphology, Chemical Composition and Optical Properties of CdS Thin Films Elaborated by Chemical Bath Deposition
}

\author{
Fouad Ouachtari $^{{ }^{*}}$, Ahmed Rmili ${ }^{1}$, Sidi El Bachir Elidrissi ${ }^{1}$, Ahmed Bouaoud ${ }^{1}$, \\ Hassan Erguig ${ }^{1}$, Philippe Elies ${ }^{2}$ \\ ${ }^{1}$ Physics Laboratory Matter and Radiation, Team Optical Spectroscopy of Solid Matter, \\ Physics Department, Faculty of Sciences, Kenitra, Morocco \\ ${ }^{2}$ Platform for Imaging and Measurement in Microscopy 6, av. Brest Cedex, France \\ E-mail: fouad489ou@gmail.com \\ Received February 1, 2011; revised May 20, 2011; accepted May 30, 2011
}

\begin{abstract}
Cadmium sulphide (CdS) thin films were deposited on glass substrates by the chemical bath deposition (CBD) method, using anhydrous cadmium chloride $\left(\mathrm{CdCl}_{2}\right)$ and thiourea $\left(\mathrm{CS}\left(\mathrm{NH}_{2}\right)_{2}\right)$ as sources of cadmium and sulphur ions respectively. The influence of bath temperature $\left(\mathrm{T}_{\mathrm{b}}\right)$, deposition time $\left(\mathrm{t}_{\mathrm{d}}\right)$ and $[\mathrm{S}] /[\mathrm{Cd}]$ ratio in the solution on the structural, morphological, chemical composition and optical properties of these films were investigated. XRD studies revealed that all the deposited films were polycrystalline with hexagonal structure and exhibited (002) preferential orientation. The films deposited under optimum conditions $\left(\mathrm{T}_{\mathrm{b}}=\right.$ $75^{\circ} \mathrm{C}, \mathrm{t}_{\mathrm{d}}=60 \mathrm{~min}$ and $[\mathrm{S}] /[\mathrm{Cd}]$ ratio $\left.=2.5\right)$ were relatively well crystallized. These films showed large final thickness and their surface morphologies were composed of small grains with an approximate size of 20 to $30 \mathrm{~nm}$ and grains grouped together to form large clusters. EDAX analysis revealed that these films were nonstoichiometric with a slight sulphur deficiency. These films exhibited also a transmittance value about $80 \%$ in the visible and infra red range.
\end{abstract}

Keywords: Cadmium Sulphide, Chemical Bath Deposition, Thin Film, Structure, Morphology, Optical Properties

\section{Introduction}

Amongst of the chalcogenide thin films like PbS, CdS, $\mathrm{ZnS}$ and $\mathrm{MnS}, \mathrm{CdS}$ appear as an interesting material for using as n-type window layer for $\mathrm{p}$-CdTe and chalcopyritebased solar cells such as p-CuInSe $e_{2}$, and/or p-Cu(In, Ga) $\mathrm{Se}_{2}$ (CIGS) [1]. This is because CdS has high transparency, wide and direct band gap transition $(2.42 \mathrm{eV})$, photoconductivity, high electron affinity and n-type conductivity. CdS can also be used in a lot of applications including electronic [2] and optoelectronic devices [3]. Undoped and doped CdS thin films have been reported using different methods: electrodeposition (ED) [4], spray pyrolysis (SP) [5], chemical bath deposition (CBD)
[6], molecular beam epitaxy (MBE) [7], metal organic vapour phase epitaxy (MOVPE) [8], successive ionic layer adsorption and reaction (SILAR) [9], and physical vapour deposition (PVD) [10]. Among these methods, the CBD technique is relatively simple, low cost compared to other methods requiring vacuum environment and its capable to yield films with good quality at optimum growth conditions.

The aim of this present work is to study the influence of some deposition parameters, such as bath temperature, deposition time and $[\mathrm{S}] /[\mathrm{Cd}]$ ratio in the solution (thiourea to cadmium chloride concentration) on the crystalline structure, surface morphology, chemical composition and optical properties of CdS thin films prepared by 
chemical bath deposition.

\section{Experimental Procedure}

CBD is a technique in which thin films are deposited on substrates immersed in dilute alkaline solution containing metal ions and the chalcogenide source. This method of deposition usually uses a complexing agent to control the slow release of metal ions $\left(\mathrm{Cd}^{2+}\right)$ and sulphur ions $\left(\mathrm{S}^{2-}\right)$ to produce the controlled homogeneous precipitation of the film on the solid substrate. When the complexing agent is ammonia $\left(\mathrm{NH}_{3}\right)$, the possible chemical reactions to form $\mathrm{CdS}$ films are as follows [11]:

$$
\begin{aligned}
\mathrm{Cd}\left(\mathrm{NH}_{3}\right)_{4}^{2+} & \leftrightarrow 4 \mathrm{NH}_{3}+\mathrm{Cd}^{2+} \\
\mathrm{CS}\left(\mathrm{NH}_{2}\right)_{2}+\mathrm{OH}^{-} & \leftrightarrow \mathrm{SH}^{-}+\mathrm{CH}_{2} \mathrm{~N}_{2}+\mathrm{H}_{2} \mathrm{O} \\
\mathrm{SH}^{-}+\mathrm{OH}^{-} & \leftrightarrow \mathrm{S}^{2-}+\mathrm{H}_{2} \mathrm{O} \\
\mathrm{Cd}^{2+}+\mathrm{S}^{2-} & \leftrightarrow \mathrm{CdS}
\end{aligned}
$$

In this work, the initial solutions to elaborate CBD$\mathrm{CdS}$ films are prepared from anhydrous cadmium chloride $\left(\mathrm{CdCl}_{2}\right)$, thiourea $\left(\mathrm{CS}\left(\mathrm{NH}_{2}\right)_{2}\right)$, ammonia $\left(\mathrm{NH}_{3}\right)$, ammonium chloride $\left(\mathrm{NH}_{4} \mathrm{Cl}\right)$. Cadmium chloride of 0.12 $\mathrm{M}$ and thiourea of $0.3 \mathrm{M}$ are employed as the cadmium and the sulfur sources, respectively. Ammonia of $10 \mathrm{M}$ is used as a complexing agent. Firstly, $3.75 \mathrm{ml}$ cadmium chloride solution is added to $112.5 \mathrm{ml}$ of de-ionized water. Thereafter, $15 \mathrm{ml}$ ammonia solution is added at the same time with $15 \mathrm{ml}$ ammonium chloride solution of 0.01 to $2 \mathrm{M}$ to adjust the $\mathrm{pH}$ at about 10 under the control of a $\mathrm{pH}$ meter. Pre-treated commercial microscope slides $\left(1.5 \times 2.5 \mathrm{~cm}^{2}\right)$ are inserted vertically into the bath and the solution is heated at appropriate temperature (between $60^{\circ} \mathrm{C}$ and $90^{\circ} \mathrm{C}$ ). Finally, when a desired temperature is obtained, $3.75 \mathrm{ml}$ of thiourea solution is added under stirring condition to ensure homogeneous distribution of the chemicals. The total volume of solution is $150 \mathrm{ml}$. After deposition, the substrates are removed from the chemical bath, and cleaned for several times with de-ionized water, then dried in air. The formed films are yellow in colour and exhibit good adherence to the substrate surfaces.

The crystal phase of the films is determined by X-ray diffraction (XRD), using $\mathrm{CuK} \alpha$ radiation with $2 \theta$ ranging from $10^{\circ}$ to $70^{\circ}$. The surface morphology of the films is determined by scanning electron microscopy (SEM) and atomic force microscopy (AFM). The chemical composition is performed with an EDAX spectrometer attached to the scanning electron microscope. In order to determine the band gap energy of the films, the optical transmission study is carried out in the wavelength range of 300 to $2500 \mathrm{~nm}$, using a SHIMADZU 3101 PC UV-VIS-
NIR spectrophotometer. The thicknesses are measured by the gravimetric method with accuracy of $10 \%$.

\section{Results and Discussion}

\subsection{Crystal Structure Determination}

Figure 1 shows the X-Ray diffraction diagrams of the $\mathrm{CdS}$ thin films deposited at bath temperature varying from 60 to $90^{\circ} \mathrm{C}$ and deposition time of $60 \mathrm{~min}$. A single diffraction peak at $2 \theta=26.7^{\circ}$ is observed. The interplanar spacing values corresponding to this diffraction peak $\left(d_{h k l}=3.34 \AA\right)$ is compared with the ASTM DATA [12]. This suggest that the obtained films are crystallized in the hexagonal structure with a preferred orientation along the (002) direction. However, R. Zhai et al. [13], O. Oladeji et al. [14] and M. Ichimura et al. [15], using chemical bath deposition and other techniques, have been found a cubic structure of the CdS films. In fact, depending on the preparation method, cadmium sulphide can exist in both sphalerite cubic and hexagonal forms, but the latter structure is more stable [6]. In addition the hexagonal structure of the $\mathrm{CdS}$ films is preferable to use in solar cell applications because the lattice parameter mismatch with $\mathrm{CuInSe}_{2}(1.2 \%)$ compared to that of cubic CdS (0.7\%). Moreover, Figure 1 shows that the whole $\mathrm{X}$-Ray diffraction diagrams exhibit a broad hump near the (002) peak at $2 \theta=26.7^{\circ}$, which is due to the glass substrate. The intensity of the (002) plane is found to be increased when increasing bath temperature up to $75^{\circ} \mathrm{C}$, which decreased afterwards. This suggests that the crystallinity of these films increases when the bath temperature increases; which is explained by the increase in films thickness due to decomposition of reactants and production of ions which is necessary for films formation. The decrease of the (002) plane intensity for films deposited at bath temperature greater than $75^{\circ} \mathrm{C}$ indicates a deterioration of the crystallinity which is attributed to the relatively lower thicknesses of the films resulted (Figure 2). The decrease of the films thickness at this temperature range is explained by the dissolution of the preformed CdS films and the desorption phenomenon [16]. The lattice parameters $a$ and $c$ are calculated from the peaks positions using the formula of hexagonal system. The values are found to be $a=4.13 \AA, c=6.70 \AA$ and $c / a=1.63$ which are close to the values published in the literature [17].

$$
\frac{1}{d_{h k l}^{2}}=\frac{4\left(h^{2}+k^{2}+h k\right)}{3 a^{2}}+\frac{l^{2}}{c^{2}}
$$

The average crystallite sizes $\left(\mathrm{D}_{\mathrm{hkl}}\right)$ of the $\mathrm{CdS}$ films are estimated from the X-ray diffraction patterns using the Scherrer formula [18]: 


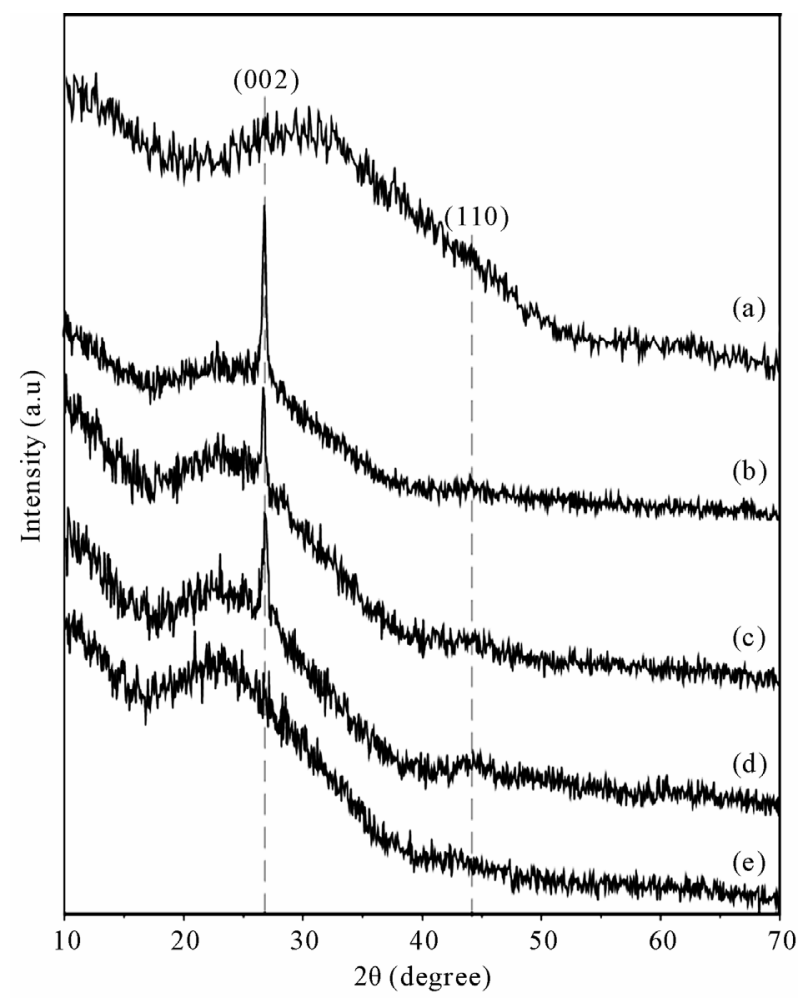

Figure 1. X-ray diffraction patterns of CdS thin films deposited at bath temperature of: (a) $\mathrm{T}_{\mathrm{b}}=70^{\circ} \mathrm{C}$, (b) $\mathrm{T}_{\mathrm{b}}=75^{\circ} \mathrm{C}$, (c) $\mathrm{T}_{\mathrm{b}}=80^{\circ} \mathrm{C}$, (d) $\mathrm{T}_{\mathrm{b}}=85^{\circ} \mathrm{C}$ and (e) $\mathrm{T}_{\mathrm{b}}=90^{\circ} \mathrm{C}$, with deposition time of $60 \mathrm{~min}$.

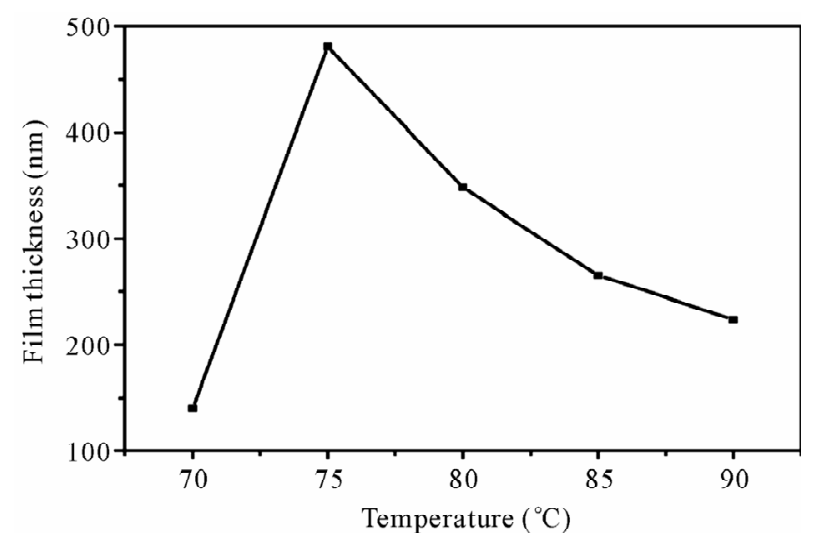

Figure 2. Variation of CdS film thickness with bath temperature at $t_{d}=60 \mathrm{~min}$.

$$
D_{h k l}=0.9 \frac{\lambda_{h k l}}{\beta_{h k l} \cos \left(\theta_{h k l}\right)}
$$

where $\lambda$ is the wavelength of incident radiation $(\lambda=$ $1.544 \AA$ ), $\beta_{h k l}$ is the full-width at half maximum (FWHM) of the respective diffraction peak and $\theta_{h k l}$ is the Bragg diffraction angle.

The calculated values are reported in Table 1. As it can be seen the values are found in the nanometer region
(15 - $21 \mathrm{~nm}$ ), indicating that the polycrystalline $\mathrm{CdS}$ films are made up of nanocrystal particles.

Figure 3 shows the X-Ray diffraction diagrams of the $\mathrm{CdS}$ thin films prepared with different deposition times at bath temperature of $75^{\circ} \mathrm{C}$. As it can be seen the intensity of the (002) plane increases with increasing deposition time (as above $60 \mathrm{~min}$ ) and then decreases when deposition time increases. This indicates that $60 \mathrm{~min}$ is the optimum deposition time for which the crystallinity of the films reaches the maximum. Figure 4 depicts the variation of the films thickness in function of deposition time. Two different regions can be observed, a first region, where the film thickness varies approximately linearly with deposition time up to $60 \mathrm{~min}$, indicating a

Table 1. Average crystallite size and thickness of the CdS thin films prepared at different bath temperatures.

\begin{tabular}{ccc}
\hline $\begin{array}{c}\text { Bath temperature } \\
\left({ }^{\circ} \mathrm{C}\right)\end{array}$ & $\begin{array}{c}\text { Average crystallite } \\
\text { size }(\mathrm{nm})\end{array}$ & Film thickness (nm) \\
\hline 70 & 11.80 & 140 \\
75 & 20.87 & 481 \\
80 & 19.11 & 348.2 \\
85 & 15.11 & 265 \\
\hline
\end{tabular}

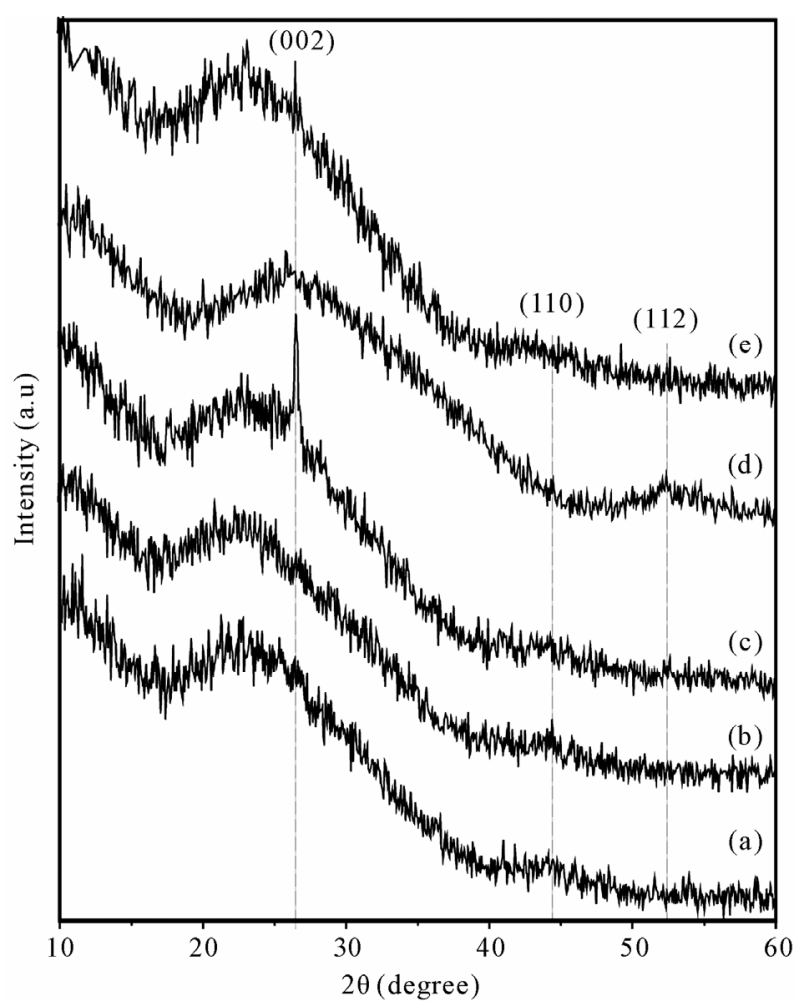

Figure 3. X-ray diffraction patterns of CdS thin films prepared with different deposition times: (a) $t_{d}=15 \mathrm{~min}$, (b) $t_{d}$ $=30 \mathrm{~min},(c) t_{d}=60 \mathrm{~min},(d) t_{d}=90 \mathrm{~min}$ and (e) $t_{d}=120$ $\min . \mathrm{T}_{\mathrm{b}}=75^{\circ} \mathrm{C}$. 


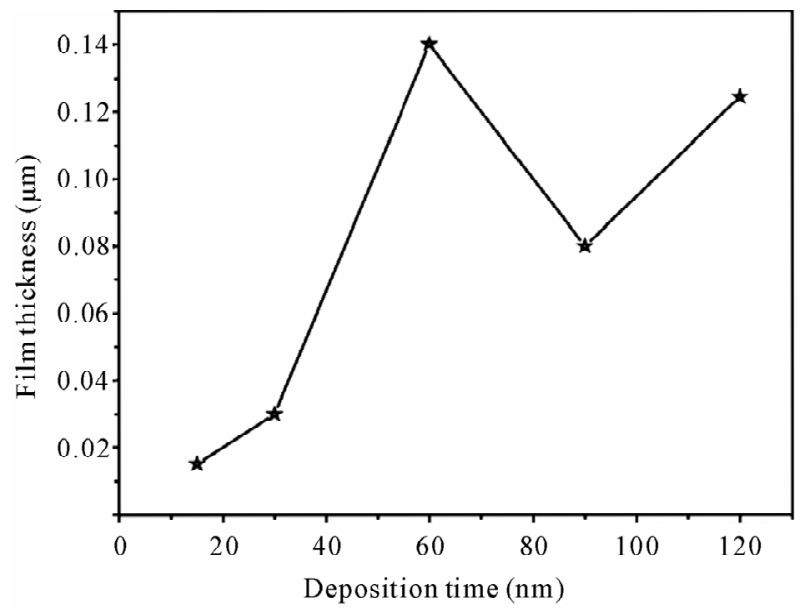

Figure 4. Variation of CdS film thickness with deposition time at $\mathrm{T}_{\mathrm{b}}=75^{\circ} \mathrm{C}$.

constant growth, and a second region, where a film growth reaches saturation and decreases when the deposition time is prolonged. The same behaviour is also observed for other chalcogenide materials such as $\mathrm{ZnS}$ [13] and $\mathrm{MnS}$ [19]. Lokhande et al. [16] have explained this phenomenon by considering two competing processes taking place in the deposition bath: one process includes the heterogeneous and homogenous precipitation of $\mathrm{CdS}$, which leads to the film growth; the other one involves the dissolution of the pre-formed $\mathrm{CdS}$ film, which result in the decrease of film thickness. In the initial time of deposition, the source materials are sufficient; the process of heterogeneous and homogenous precipitation play a more important role than the dissolution process, leading to the increase in film thickness. When the deposition time is prolonged ( $60 \mathrm{~min}$ in our case), the source materials become less. Therefore, the dissolution process predominates over the heterogeneous and homogeneous precipitation, resulting in the decrease of film thickness.

Figure 5 shows the X-Ray diffraction diagrams of the $\mathrm{CdS}$ thin films prepared with different $[\mathrm{S}] /[\mathrm{Cd}]$ ratios. The intensity of the (002) plane is found to be increased when increasing $[\mathrm{S}] /[\mathrm{Cd}]$ ratio up to 2.5 , which decreased afterwards. The decrease of the crystallinity for the films deposited with $[\mathrm{S}] /[\mathrm{Cd}]$ ratio greater than 2.5 is attributed to the decrease in films thickness. Figure 6 presents the variation of the films thickness with the $[\mathrm{S}] /[\mathrm{Cd}]$ ratio in the solution. As it can be seen, the thickness reaches the maximum when the films are deposited with $[\mathrm{S}] /[\mathrm{Cd}]$ ratio equals to 2.5 , this is agree with the R. Mendoza-Pérez et al. work [20]. The decrease of the films thickness for films prepared with $[\mathrm{S}] /[\mathrm{Cd}]$ ratio greater than 2.5 is probably due to the dissolution process of the preformed CdS films and the desorption phenomenon, which are predominates over the heterogeneous and homogeneous process.

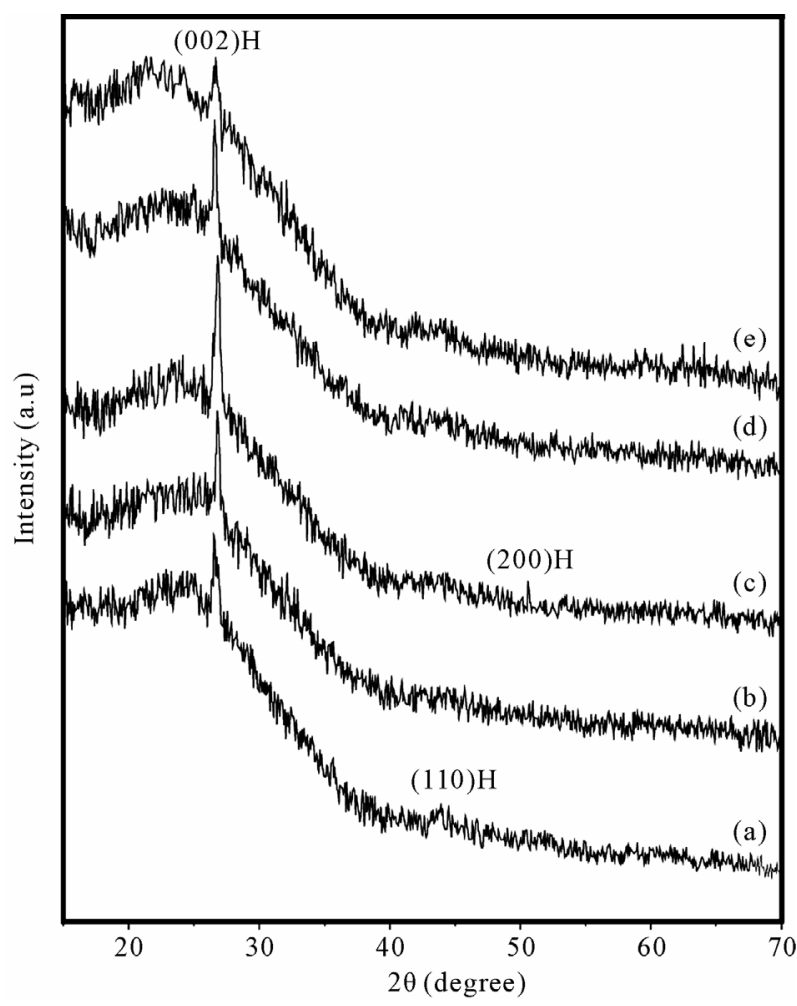

Figure 5. X-ray diffraction patterns of CdS thin films elaborated with different $[S] /[C d]$ ratios: (a) $[S] /[C d]=1$, (b) $[\mathrm{S}] /[\mathrm{Cd}]=2$, (c) $[\mathrm{S}] /[\mathrm{Cd}]=2.5$, (d) $[\mathrm{S}] /[\mathrm{Cd}]=3$ and (e) $[\mathrm{S}] /[\mathrm{Cd}]=5$.

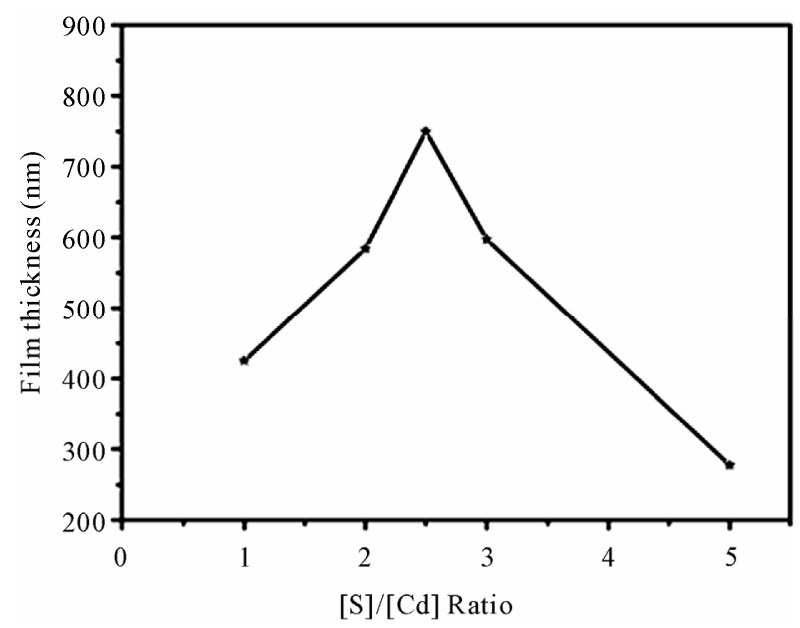

Figure 6. Variation of CdS film thickness with [S]/[Cd] ratio. $t_{d}=60 \mathrm{~min}, T_{b}=75^{\circ} \mathrm{C}$.

\subsection{Surface Morphology}

The influence of the temperature on the morphology of the CdS films is shown in Figure 7. It is clearly seen that the average crystallite size decreases with increasing temperature. For $\mathrm{T}=90^{\circ} \mathrm{C}$, no grains are observed indicating an amorphous phase for films prepared at this 


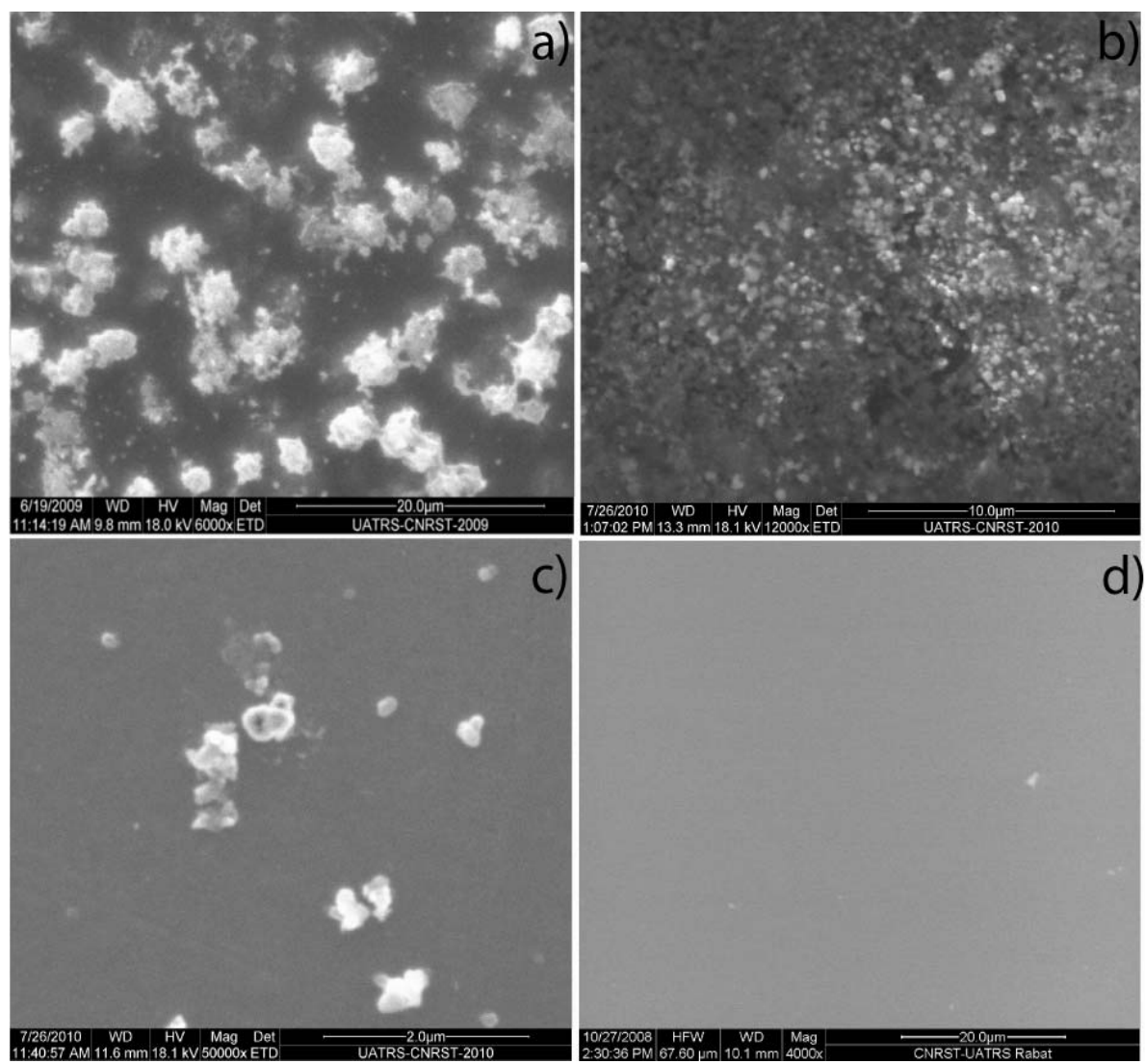

Figure 7. SEM micrographs of CdS thin films deposited at bath temperature of: (a) $\mathrm{T}_{\mathrm{b}}=75^{\circ} \mathrm{C},(\mathrm{b}) \mathrm{T}_{\mathrm{b}}=80^{\circ} \mathrm{C},(\mathrm{c}) \mathrm{T}_{\mathrm{b}}=85^{\circ} \mathrm{C}$ and (d) $\mathbf{T}_{\mathrm{b}}=90^{\circ} \mathrm{C}$.

temperature. These results are in agreement with those obtained by X-ray diffraction (Table 1).

The SEM micrographs of the surface morphology of the CdS films prepared with different $[\mathrm{S}] /[\mathrm{Cd}]$ ratios in the solution (1, 2, 2.5, 3 and 5) are shown in Figure 8. These micrographs show that the obtained films have good adherence on the substrates without pinholes or cracks. Moreover, The films are covered by spherical grains, whose size decreases and their density increases noticeably when $[\mathrm{S}] /[\mathrm{Cd}]$ ratio increases. When $[\mathrm{S}] /[\mathrm{Cd}]$ ratio is 1 (Figure $\mathbf{8 ( a )}$ ), the small particles accumulate continuously and cover the entire surface of the substrate leading to an homogeneous layer. This indicates that the mechanism film formation is due to ion-by-ion deposition (heterogeneous mechanism). When $[\mathrm{S}] /[\mathrm{Cd}]$ ratio increase up to 1 , a small particles are grouped to form larger clusters discreetly distributed in the films as it is shown clearly in Figures 8(b)-(e). This indicates that the mechanism film formation is due to cluster-by-cluster deposition (homogeneous mechanism). The average crystallite size of these films varies between 500 and $1000 \mathrm{~nm}$ while that estimated by Scherrer's equation is $21 \mathrm{~nm}$. This value is much less than that from SEM. This is can be explained by agglomeration of small particles of the CdS to form large clusters. To have more details on the surface morphology of the CdS films, the AFM analysis is used.

Figure 9 presents 3D AFM images obtained by scanning an area of $2 \mu \mathrm{m} \times 2 \mu \mathrm{m}$ (Figure 9(a)), $20 \mu \mathrm{m} \times 20$ $\mu \mathrm{m}$ (Figure 9(b)) and $20 \mu \mathrm{m} \times 20 \mu \mathrm{m}$ (Figure 9(c)) of the surface of the CdS films deposited with ratio $[\mathrm{S}] /[\mathrm{Cd}]=$ 2.5 at $75^{\circ} \mathrm{C}$ and deposition time of $30 \mathrm{~min}, 75^{\circ} \mathrm{C}$ and deposition time of $60 \mathrm{~min}$ and $85^{\circ} \mathrm{C}$ and deposition time of $60 \mathrm{~min}$, respectively. They show that the surfaces are composed of small grains with an approximate size of 20 to $30 \mathrm{~nm}$ and grains grouped together to form large clusters like a cauliflower with a mean size of 200 to $500 \mathrm{~nm}$, confirming the results obtained by X-ray diffraction analysis and SEM, respectively. Moreover, the film deposited with a short deposition time $(30 \mathrm{~min})$ (Figure 9(a)) shows a strong surface roughness (50 to $60 \mathrm{~nm}$ ) compared to that of film (30 to $40 \mathrm{~nm}$ ) prepared with a long deposition time (60 min) (Figure 9(b)), suggesting that, at the beginning, the mechanism CdS films formation is probably due to clusters-by-clusters deposition (homogeneous mechanism). On the other hand, when the bath temperature is reached to $85^{\circ} \mathrm{C}$, none a significant improvement in the surface roughness is noticed. 

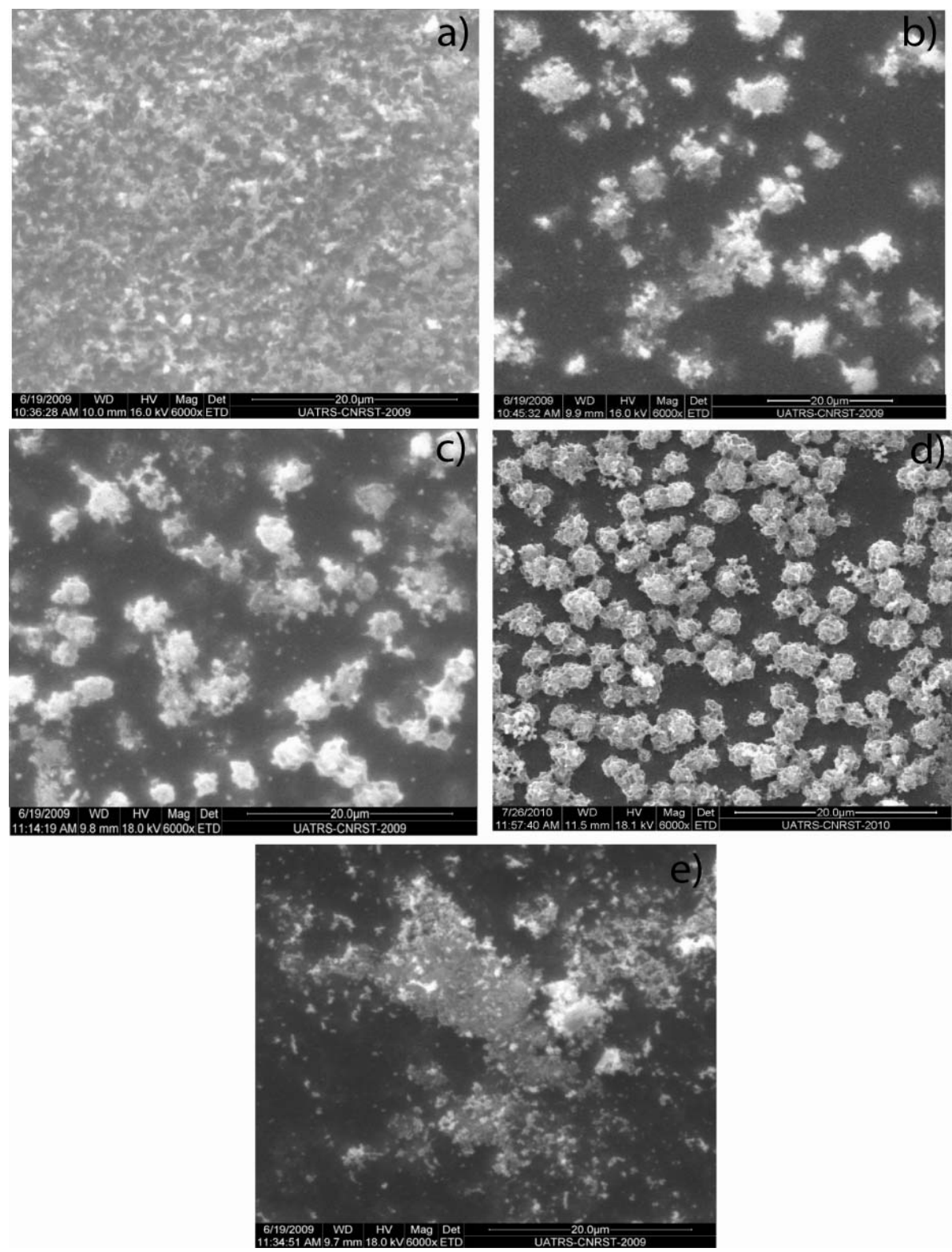

Figure 8. SEM micrographs of CdS thin films deposited with different $[\mathrm{S}] /[\mathrm{Cd}]$ ratios: (a) $[\mathrm{S}] /[\mathrm{Cd}]=1,(\mathrm{~b})[\mathrm{S}] /[\mathrm{Cd}]=2,(\mathrm{c})$ $[\mathrm{S}] /[\mathrm{Cd}]=2.5,(\mathrm{~d})[\mathrm{S}] /[\mathrm{Cd}]=3$ and $(\mathrm{e})[\mathrm{S}] /[\mathrm{Cd}]=5$.

\subsection{Composition Analysis}

Figure 10 presents the EDAX spectrum of the CdS thin films prepared under optimum growth conditions. It shows peaks of $\mathrm{Cd}, \mathrm{S}$ and some impurities like, $\mathrm{Si}, \mathrm{Ca}$, $\mathrm{Na}$ and $\mathrm{O}$ which are originated probably from the glass substrates and deionised water, respectively. The atomic concentrations from EDAX analysis and the calculated atomic ratio are presented in Table 2 . As it can be seen, the $[\mathrm{S}] /[\mathrm{Cd}]$ atomic ratio is 0.94 suggesting the presence of sulphur vacancies (excess of cadmium) in the deposited films, which act as donors, leading to n-type conductivity.

\subsection{Optical Properties}

The optical properties such as transmittance, absorption coefficient and band gap energy of CdS thin films are determined from the variation of the optical transmission with wavelength $(\lambda)$ in the range of 300 to $1500 \mathrm{~nm}$ (Table 1). Figure 11 shows plots of optical transmission of the CdS films deposited at different bath temperatures. The films produced at optimum conditions $\left(T_{b}=75^{\circ} \mathrm{C}\right)$ are found relatively to be highly transparent of about $80 \%$ in the visible and near infra-red regions. This is can be explained by a less light scattering of these films due to their smoothest surfaces. The similar phenomenon has 


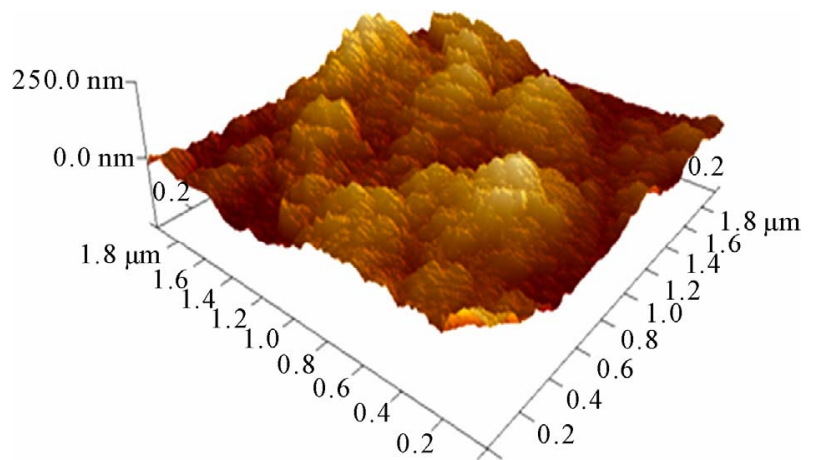

(a)

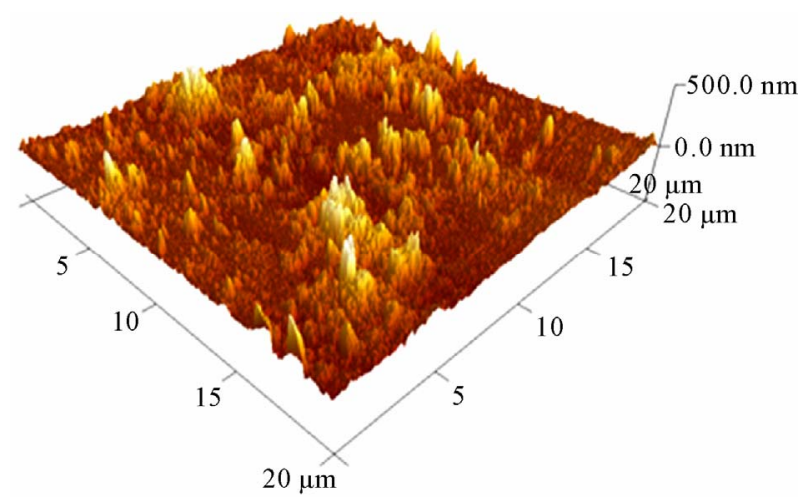

(b)

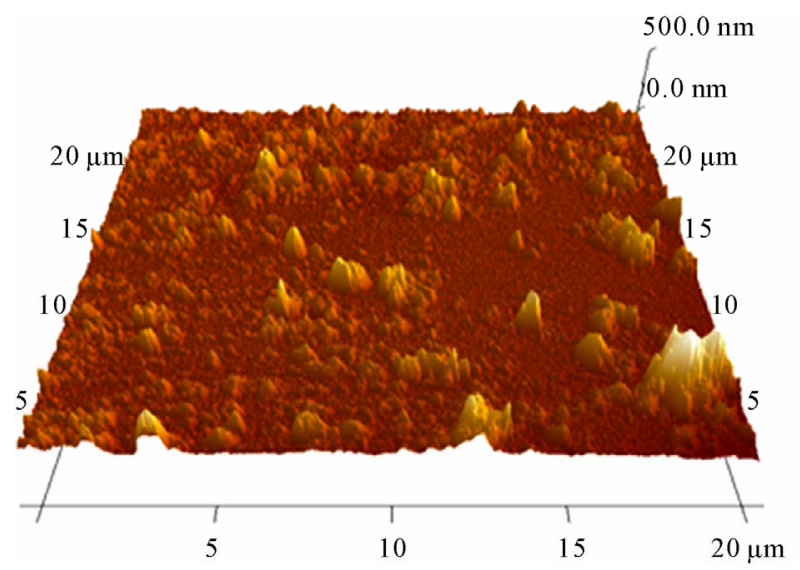

(c)

Figure 9. 3D AFM micrographs of CdS thin films deposited with $[S] /\left[C d=2.5\right.$ at: (a) $T_{b}=75^{\circ} \mathrm{C}$ and $t_{d} 30 \mathrm{~min}$, (b) $T_{b}=$ $75^{\circ} \mathrm{C}$ and $t_{d}=60 \mathrm{~min}$, (c) $T_{b}=85^{\circ} \mathrm{C}$ and $t_{d}=60 \mathrm{~min}$.

been reported in the literature [21,22].

By using the Tauc relationship which is given by the formula [23]:

$$
(\alpha h v)=A(h v-E g)^{n}
$$

In witch, $h v$ is the photon energy, $E g$ is the optical band gap of the semiconductor, $A$ is a constant and $n=$ $1 / 2$ for direct band gap semiconductor such as CdS, the
Table 2. EDAX analysis of the CdS thin films deposited under optimum conditions: $T_{b}=75^{\circ} \mathrm{C}, t_{d}=60 \mathrm{~min}$ and $[\mathrm{S}] /[\mathrm{Cd}]=\mathbf{2 . 5}$.

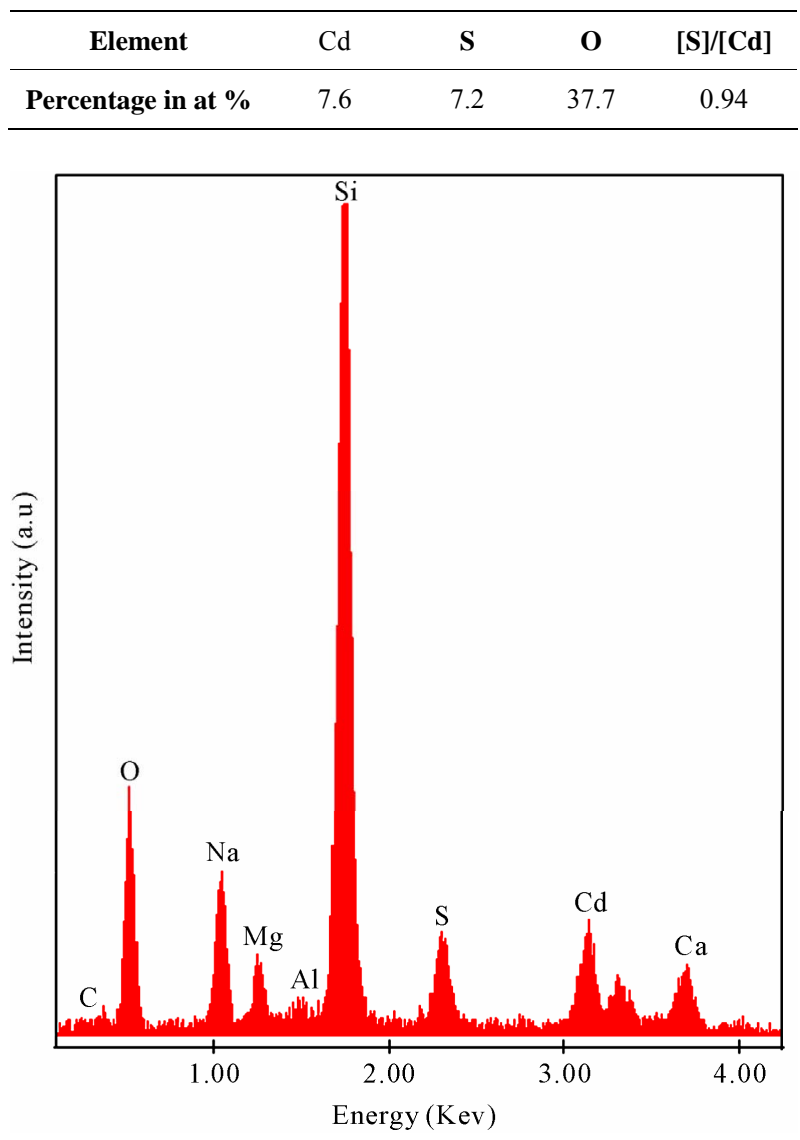

Figure 10. EDAX spectrum of CdS thin film deposited under optimum conditions: $T_{b}=75^{\circ} \mathrm{C}, t_{d}=60 \mathrm{~min}$ and $[S] /[\mathrm{Cd}]$ $=2.5$.

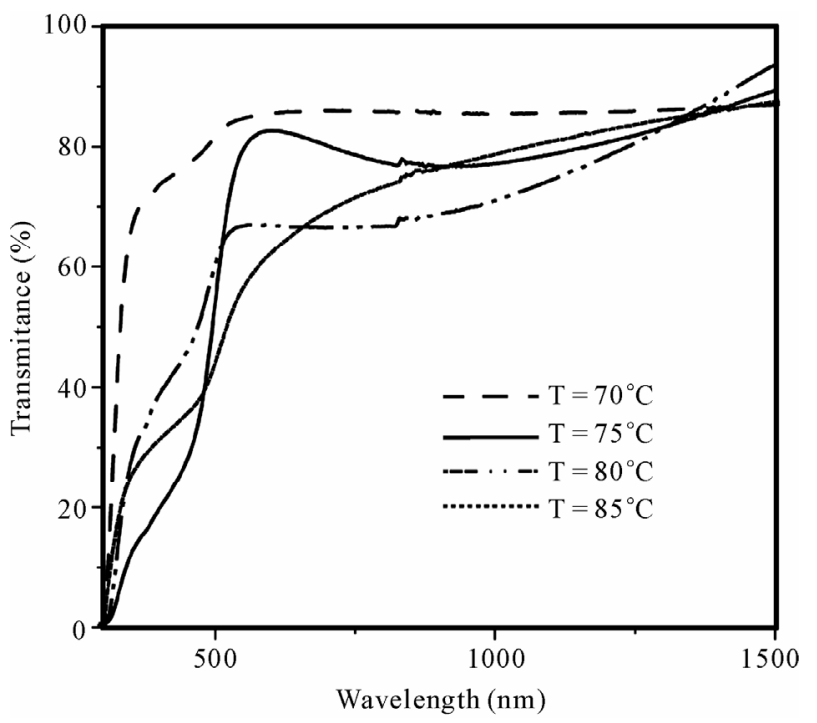

Figure 11. Optical transmission spectra of CdS thin films prepared at different bath temperatures. 
optical band gap value of the CdS thin films is estimated by extrapolation of the straight line of the plot of $(\alpha h v)^{2}$ versus photon energy as it is shown in Figure 12. We found that the value of $E g$ for the films prepared at different temperatures varies from 2.40 to $2.46 \mathrm{eV}$, which is in agreement with the value reported by other authors $[21,24]$.

The effect of $[\mathrm{S}] /[\mathrm{Cd}]$ ratio on the optical properties of CdS films deposited at $\mathrm{T}=75^{\circ} \mathrm{C}$ and $\mathrm{t}_{\mathrm{d}}=60 \mathrm{~min}$ is studied. Figure 13 shows the optical transmittance spectra of the CdS films elaborated with different $[\mathrm{S}] /[\mathrm{Cd}]$ ratios. As it can be seen, the films elaborated with $[\mathrm{S}] /[\mathrm{Cd}]$ ratio equals 2.5 exhibit a high transmission of about $80 \%$ in the visible and near infra-red regions. This can be explained relatively by a good cristallinity and stiochiometry of these films as it is found by X-ray diffraction and EDAX analysis. The optical band gap of these films is also calculated by extrapolation of the straight line of the plot of $(\alpha h v)^{2}$ versus photon energy as it is shown in Figure 14. The values of $E g$, average transmittance (\%T) and average crystallite size $\left(D_{h k l}\right)$, are compiled in Table 3. It can be observed that the CdS films prepared with $[\mathrm{S}] /[\mathrm{Cd}]=2.5$ have high average transmission of about $80 \%$ in the visible and infrared regions, large band gap of $2.44 \mathrm{eV}$, which is close to the $E g$ value reported for single crystalline CdS $(2.43 \mathrm{eV})$ and relatively large grain size.

\section{Conclusions}

CdS thin films were deposited on glass substrates by the CBD method using a solution of cadmium chloride and thiourea as sources of cadmium and sulphur ions, respectively. The optimal deposition parameters were found to be $\mathrm{T}_{\mathrm{b}}=75^{\circ} \mathrm{C}, \mathrm{t}_{\mathrm{d}}=60 \mathrm{~min}$ and $[\mathrm{S}] /[\mathrm{Cd}]=2.5$. The films prepared under these optimal conditions were relatively well crystallized and had hexagonal structure with a preferential orientation along the (002) direction. These films showed also large final thickness and their surface morphologies were composed of small grains with an approximate size of 15 to $25 \mathrm{~nm}$ and grains grouped together to form large clusters like a cauliflower. The composition study showed that these films were nonstoichiometric with a slight sulphur deficiency leading to $\mathrm{n}$ type conductivity. These films exhibited also a good transmittance of about $80 \%$ in visible and near infra-red regions of the electromagnetic spectrum so it is possible to us them as a window layer in high efficiency thin film solar cells based on $\mathrm{CdTe}$ and $\mathrm{Cu}(\mathrm{In}, \mathrm{Ga}) \mathrm{Se}_{2}$ (CIGS).

\section{Acknowledgements}

The authors are gratefully to "Platform for Imaging and

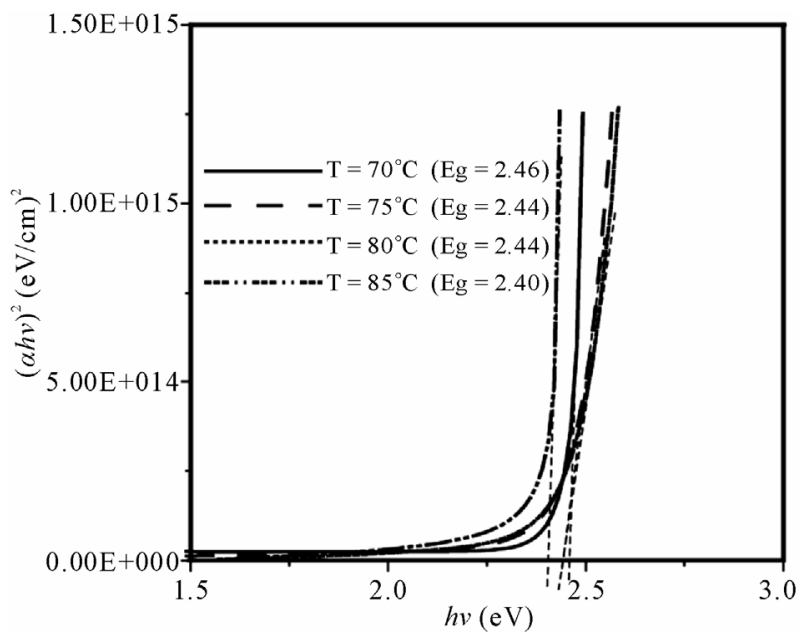

Figure 12. Variation of $(\alpha h v)^{2}$ with photon energy $(h v)$ for CdS thin films elaborated at different bath temperatures.

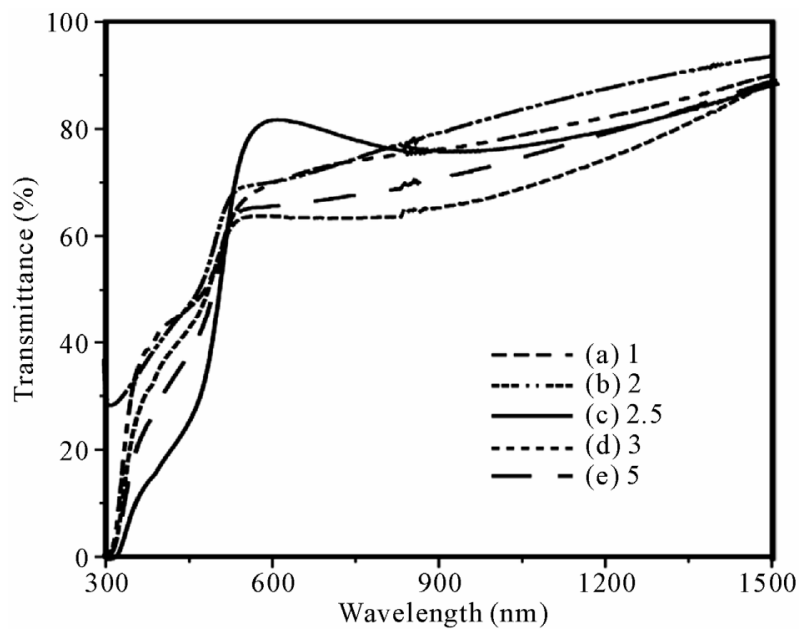

Figure 13. Optical transmission spectra of CdS thin films prepared with different $[\mathrm{S}] /[\mathrm{Cd}]$ ratios.

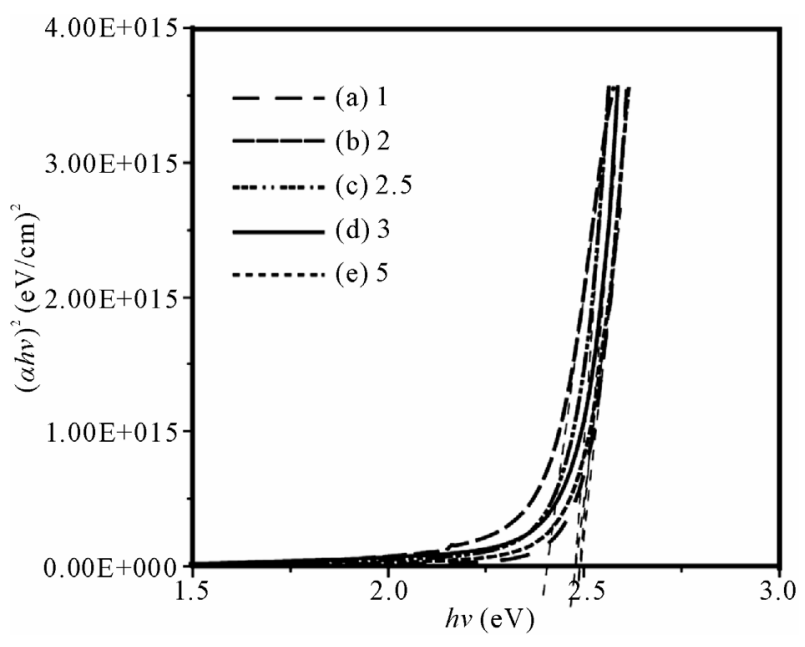

Figure 14. Variation of $(\alpha h v)^{2}$ with photon energy $(h v)$ for CdS thin films elaborated with different $[S] /[C d]$ ratios. 
Table 3. Average crystallite size $\left(D_{h k l}\right)$, band gap $(E g)$ and average transmittance values (\%T) of the CdS thin films with varying ratios of $[S] /[C d]$.

\begin{tabular}{cccc}
\hline$[\mathrm{S}] /[\mathrm{Cd}]$ & $\operatorname{Eg}(\mathrm{eV})$ & $\begin{array}{c}\text { Average transmittance } \\
(\%)\end{array}$ & $\begin{array}{c}\text { Average crystallite } \\
\text { size }(\mathrm{nm})\end{array}$ \\
\hline 1 & 2.37 & 69 & 11.84 \\
2 & 2.39 & 71 & 16.51 \\
2.5 & 2.44 & 79 & 20.87 \\
3 & 2.42 & 75 & 18.34 \\
5 & 2.36 & 66 & 9.90 \\
\hline
\end{tabular}

Measurement in Microscopy of University of Brest, France" for assistance in AFM measurements.

\section{References}

[1] M. Contreras, M. Romero, B. To, F. Hasoon, R. Noufi, S. Ward and K. Ramanathan, "Optimization of CBD CdS Process in High-Efficiency $\mathrm{Cu}(\mathrm{In}, \mathrm{Ga}) \mathrm{Se} 2$-Based Solar Cells," Thin Solid Films, Vol. 403-404, No. 579, 2002, pp. 204-211.

[2] A. Davis, K. Vaccaro, H. Dauplaise, W. Waters and J. Lorenzo, "Optimization of Chemical Bath-Deposited Cadmium Sulfide on InP Using a Novel Sulfur Pretreatment," Journal of The Electrochemical Society, Vol. 146, No. 3, 1999, pp. 1046-1053.

[3] O. Vigil-Galan, J. Ximello-Quiebras, J. Aguilar-Hernandez, G. Contreras-Puente, A. Cruz-Orea, J. Mendoza-Alvarez, J. Cardona-Bedoya, C. Ruiz and V. Bermudez, "Passivation Properties of Cds Thin Films Grown by Chemical Bath Deposition on Gasb: The Influence of the S/Cd Ratio in the Solution and of the Cds Layer Thickness on the Surface Recombination Velocity," Semiconductor Science and Technology, Vol. 21, 2006, pp. 76.

[4] M. Ilieva, D. Dimova-Malinovska, B. Ranguelov and I. Markov, "High Temperature Electrodeposition of Cds Thin Films on Conductive Glass Substrates," Journal of Physics: Condensed Matter, Vol. 11, No. 49, 1999, pp. 10025-10031.

[5] A. Aschour, "Physical Properties of Spray Pyrolysed CdS Thin Films," Turkish Journal of Physics, Vol. 17, No. 8, 2003, pp. 551-558.

[6] B. Pradhan, A. K. Sharma and A. K. Ray, "Conduction Studies on Chemical Bath Deposition Nanocrystalline Cds Thin Films," Journal of Crystal Growth, Vol. 304, No. 2, 2007, pp. 388-392.

[7] P. Boieriu, R. Sporken, Y. Xin, N. Browning and S. Sivananthan, "Wurtzite CdS on CdTe Grown by Molecular Beam Epitaxy," Journal of Electronic Materials, Vol. 29, No. 6, 2000, pp. 718-722.

[8] H. Uda, H. Yonezawa, Y. Ohtsubo, M. Kosaka and H. Sonomura, "Thin CdS Films Prepared by Metalorganic Chemical Vapor Deposition," Solar Energy Materials and Solar Cells, Vol. 75, 2003, pp. 219-226.

[9] M. Sasagawa and Y. Nosaka, "The Effect of Chelating Reagents on the Layer-by-Layer Formation of Cds Films in the Electroless and Electrochemical Deposition Processes," Electrochimica Acta, Vol. 48, No.5, 2003, pp. 483-488.

[10] R. W. Birkmire, B. E. McCandless and S. S. Hegedus, "Optimization of Vapor Post-Deposition Processing for Evaporated CdS/CdTe Solar Cells," Solar Energy, Vol. 12, 1992, pp. 37-45.

[11] G. Hodes, "Chemical Solution Deposition of Semiconductors Films," Marcel Dekker, Inc., Basel, New York, 2003.

[12] ASTM DATA (6-0314).

[13] R. Zhai, S. Wang, H. Xu, H. Wang and H. Yan, "Rapid Formation of $\mathrm{CdS}, \mathrm{ZnS}$ Thin Films by MicrowaveAssisted Chemical Bath Deposition," Matarials Letters, Vol. 59, No. 12, 2005, pp. 1497-1501.

[14] O. Oladeji, L. Chow, J. R. Liu, W. K. Chu, A. N. P. Bustamante, C. Fredricksen and A. F. Schulte, "Comparative Study of Cds Thin Films Deposited by Single, Continuous, and Multiple Dip Chemical Processes," Thin Solid Films, Vol. 359, No. 2, 2000, pp. 154-159.

[15] M. Ichimura, F. Goto and E. Arai, "Structural and Optical Characterization of Cds Films Grown by Photochemical Deposition," Journal of Applied Physics, Vol. 85, No. 10, 1999, pp. 7411-7417.

[16] C. D. Lokhande, A. Ennaoui, P. S. Patil, M. Giersig, M. Muller, K. Diesner and H. Tribursch, "Process and Characterisation of Chemical Bath Deposited Manganese Sulphide (MnS) Thin Films," Thin Solid Films, Vol. 330, No. 2, 1998, pp. 70-75.

[17] S. Prabahar and M. Dhanam, "CdS Thin Films from Two Different Chemical Baths-Structural and Optical Analysis," Journal of Crystal Growth, Vol. 285, No. 1-2, 2005 , pp. 41-48.

[18] L. D. Kadam and P. S. Patil, "Thickness-Dependent Properties of Sprayed Cobalt Oxide Thin Films," Materials Chemistry and Physics, Vol. 68, No. 1-3, 2001, pp. 225-232.

[19] D. Fan, H. Wang, Y. Zhang, J. Cheng. B. Wong. H. Yan, "Preparation of Crystalline MnS Thin films by Chemical Bath Deposition," Materials Chemistry and Physics, Vol. 80, 2003, pp. 44-47.

[20] R. Mendoza-Pérez, G. Santana-Rodriguez, J. Sastre-Hernan- dez, A. Morales-Acevedo, A. Arias-Carbajal, O. Vigil- Galan, J. C. Alonso and G. Contreras-Puente, "Effects of Thiourea Concentration on CdS Thin Films Grown by Chemical Bath Deposition for CdTe Solar Cells," Thin Solid Films, Vol. 480-481, 2005, pp. 173176.

[21] F. Y. Liu, Y. Q. Lai, J. Liu, B. Wang, S. S. Kuang, Z. A. Zhang, J. Li and Y. X. Liu, "Characterization of Chemical Bath Deposited CdS Thin Films at Different Deposition Temperature," Journal of Alloys and Compounds, Vol. 493, No. 1-2, 2010, pp. 305-308.

[22] K. S. Ramaiah, R. D. Pilkington, A. E. Hill, R. D. 
Tomlinson and A. K. "Structural and Optical Investigations on Cds Thin Films Grown by Chemical Bath Technique," Materials Chemistry and Physics, Vol. 68, No. 1-3, 2001, pp. 22-30.

[23] J. Tauc, "Amorphous and Liquid Semiconductors," Ple- num Press, New York, 1974, pp. 159-220.

[24] L. Wenyi, C. Xun, C. Qiulong and Z. Zhibin, "Influence of Growth Process on the Structural, Optical and Electrical Properties of CBD-Cds Films," Materials Letters, Vol. 59, No. 1, 2005, pp. 1-5. 